\title{
Food and Population: A Long View
}

\author{
GLIFTON B. LUTTRELL
}

Writis

ITH the sharp increase in food prices in 1973 and 1974, the world food-population ratio began to receive increasing attention. Writers in both professional journals and more widely read magazines have pointed to the prospect of rising world food costs and starvation in the years ahead. ${ }^{3}$

The recent predictions, that per capita food production will decine, are consistent with the basic classical argument of the early 1800's that the growth rate of the world population tends to exceed that of food production. These views are founded on presumptions of major constraints to increasing crop yields and a continuing high rate of world population growth. ${ }^{2}$ The alleged constraints to food production growth, however, give little recognition to the diversity of the food-population problems among different

\footnotetext{
1 Writings which represent these views include: Paul $R$ Ehrlich, The Population Bomb (New York: Ballantine Books, 1968); Lawrence A. Mayer, "We Can't Take Food for Granted Arymore," Fortune (February 1974), pp. 85-89 and 132-36; Gene Karetz, "The Global Food Shortage," Business Week, June 8, 1974, p. 63; "The Fat Years and the Lean," The Economist, (November 2, 1974), p. 19; "Formula for World Famine?", U.S. Netos and World Report, January 28, 1974, pp. 50-52; Wayne Bartholomew and George A. Wing, "Profiles of the Future, Arab Petroleum = American Food," Business Horizons (Indiana University Graduate School of Business, Vol. XVII, Number 6, December 1974), pp. 5-14, "In the End, Even U.S. May Not Be Able to Feed the World," U.S. News and World Report, May 27, 1974, pp 57-58; Lester R. Brown and Eitik P. Eckholm, "Food and Hunger: The Balance Sheet," Challenge (September-October 1974), pp. 12-24, Willard W. Cochrane, "Food, Agriculture, and Rural Welfare: Domestic Policies in an Uncertain World," American Journal of Agricultural Economics, Volume 56, Number 5 (December 1974), pp. 989-997; and "U.S. Food Power: Ultimate Weapon in World Politics," Business Week, December 15, 1975, pp. 54-60.

${ }^{2}$ Ehrlich, Population Bomb, pp. 44 and 46-47; Brown and Eckholm, "Food and Hunger," pp. 12-24; and Cochrane, "Food Agriculture and Rural Welfare," pp. 989-91.
}

economies of the world, let alone take account of the economic factors which affect the incentive to reduce food production costs.

This article postulates that the United States and the other more developed nations (MDCs) will not experience rising real food costs over the longer run despite some increase in the early 1970 s and the numerous reports which point to world famine. It hypothesizes that the food-population ratio in the various nations of the world is largely a function of the size and composition of per capita wealth, and that per capita wealth remains near the subsistence level for most of the less developed nations (LDCs). Consequently, they are still subject to periodic famines. However, famines in the LDCs will not spill over into the MDCs which have gradually increased per capita wealth and been free from famines for more than a century.

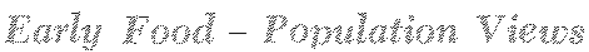

Predictions of rising food scarcity and limits to productivity growth are not of recent origin. Such allegations can be traced back several centuries. They became widely accepted following the writings of the classical economists in the late $1700 \mathrm{~s}$ and early $1800 \mathrm{~s}$. Giovanni Botero in 1589 postulated that population tends to increase to the limits imposed by the means of subsistence. ${ }^{3}$ Adam Smith contended that the means of subsistence limits the multiplication of humans and all other species of animals. ${ }^{*} \mathrm{He}$ and

\footnotetext{
3loseph A. Schumpeter, History of Economic Analysis (New York: Oxford University Press, 1954), pp. 254-55.

${ }^{4}$ Adam Smith, The Wealth of Nations (New York: The Modern Library, 1937), pp. 79, 81 .
} 
other classical economists viewed the food producing qualities of land as being highly inelastic with respect to other inputs. They believed that any gains in yields resulting from new technology would be quickly offset by population growth. ${ }^{5}$

David Ricardo, a leading proponent of the classical view on returns to land, reasoned that (1) rent arises because of differences in soil fertility; (2) the value of production on the unit of least fertile land in use will only be sufficient to cover costs of nonland inputs thus yielding no rent; (3) labor values are determined by returns to labor on the less fertile acres; and (4) marginal productivity of labor will decline over time as the population increases and additional marginal acres are brought under cultivation.

The proponents of this view held that the total volume of real wages is relatively fixed, being limited to a worker's output on the least fertile land times the total number of workers. Consequently, as population increases, per capita real wages were expected to decline, and starvation among the marginal nonlanded classes was expected to become widespread. On the other hand, returns to the landed classes would tend to rise since the difference in yield between the more fertile and the marginal acres would be greater and rents higher. ${ }^{6}$

Thomas Malthus, the leading proponent of the classical starvation view, contended that there is no limit to the prolific reproduction of people except when imbalances resulting from their crowding interfere with each other's means of subsistence. He postulated that under favorable conditions the means of subsistence might increase in an arithmetic ratio, whereas population tends to increase in a geometric ratio, doubling each twenty-five years. ${ }^{7}$

James Mill and other early $19 t h$ century writers further developed the subsistence argument into a wages-fund theory. Mill substituted all forms of capital for land in the Malthusian model and argued that a decrease in the ratio of capital to population over time will cause (real) wages to decline, implying a reduction in per capita output of all goods and services including food. Like Malthus he believed that population tended to increase at a faster rate than

5Smitli, The Wealth of Nations, pp. 94-95; David Ricardo, The Principles of Political Economy and Taxation (London: J. M. Dent and Sons, Ltt, 1948), p, 279-80, and Thomas Robert Malthus, On Population, ed. Gertrude Himmelfarb (New York: Random House, 1960), pp. 151-57.

6Ricardo, Principles, pp. 273-92.

7Malthus, On Population, pp. 154, 156.

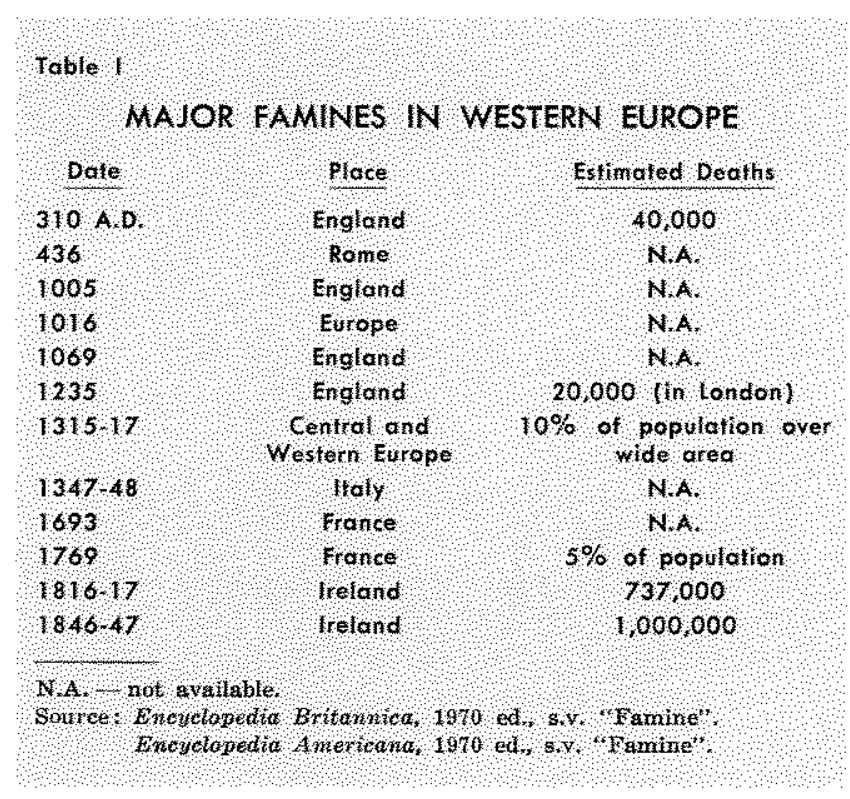

capital, and was held in check by the limits on real wages, i.e. the means of subsistence. ${ }^{8}$

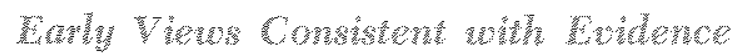

The classical food supply views appear to explain population growth throughout most of recorded history. Prior to the industrial revolution in the $1800 \mathrm{~s}$, per capita wealth and production was relatively low throughout the world and famines occurred frequently even in the more developed areas. Some periods of major famine reported in Western Europe are listed in Table I. The great Irish famine of 1846-47 following the failure of the Irish potato crop was the last major famine to occur during peacetime in either Western Europe or the United States. The population of Ireland declined more than two million, or about 25 percent as a result of the famine, related deaths, and migrations.

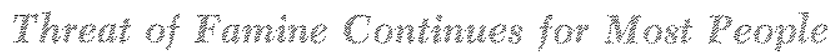

World food production per capita has trended up in recent decades, but the overall improvement has been relatively modest. Food production per capita rose one percent per year during the decade 1954-64 and about 0.8 of a percent per year during the decade 1964-74 (Table II). Total food production rose at rates of 3.0 and 2.7 percent, respectively, in the two decades. However, population growth was maintained at a 1.9 percent rate throughout both decades, offsetting much of the increase in food production.

8James Mill, Elements of Political Economy, Reprints of Economic Classics (New York: August M. Kelley, Bookseller, $1963)$, pp. $40-50$. 


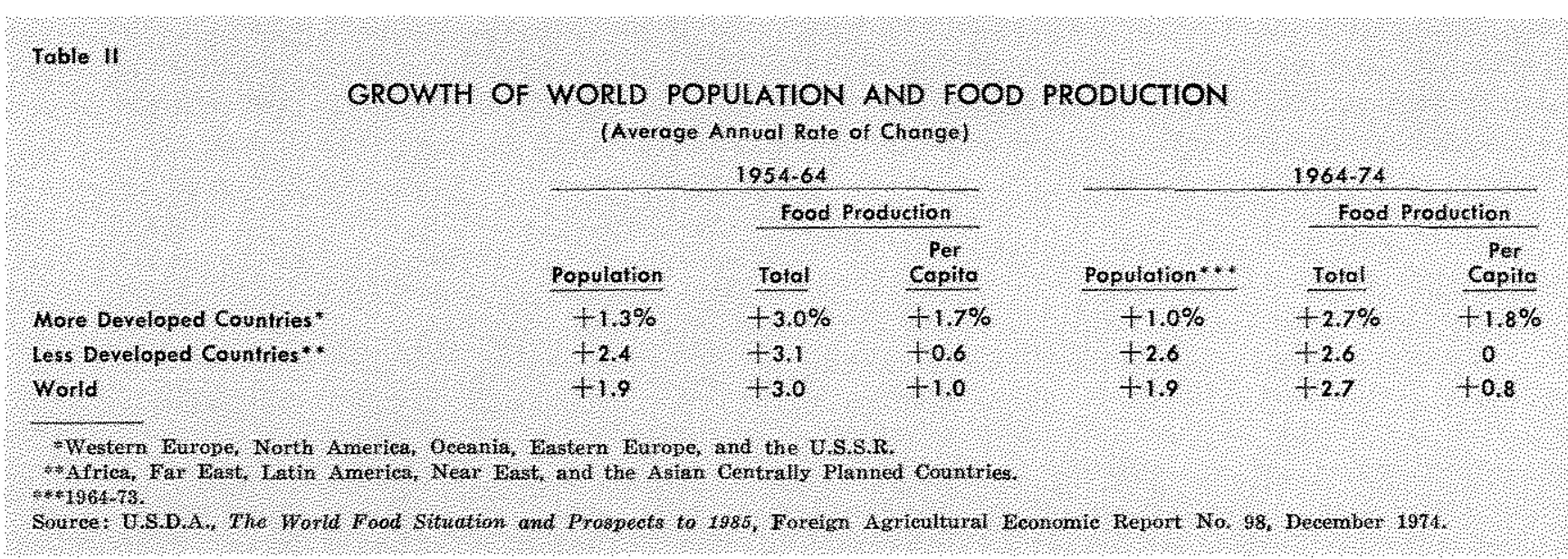

Furthermore, the rate of increase in food production per person varied widely among the world economies. During the decade ending in 1974 all the per capita increase occurred in the MDCs. The rate of increase in total food production in the LDCs declined from 3.1 to 2.6 percent per year from the decade ending in 1964 to the decade ending in 1974, about the same as that in the MDCs. However, the population growth rate in the $L D C$ Cs rose from 2.4 percent in the decade ending in 1964 to 2.6 percent in the latter decade, whereas the population growth rate in the MDCs declined from 1.3 to 1.0 percent (Table II). The rise in population during the latter decade in the LDCs exactly offset the increase in total food output while food production per capita continued up in the MDCs at about the same rate as in the earlier decade. Furthermore, more than a third of the LDCs experienced a decline in per capita food production during the 20 years ending in 1972 .

Many people in the LDCs, which include Latin America, and most of Asia and Africa, probably remain near the Malthusian level of subsistence. These nations have relatively high rates of population growth and low rates of capital accumulation and productivity per capita both on their farms and in other industries. They add about 61 million to the world's population each year and account for 86 percent of the world's annual population increase ${ }^{9}$ More recent comparisons indicate a leveling of in the population growth rates of these regions; however, there is still little tendency for their rates of population growth to decline.

Reflecting the low productivity levels in the LDCs, their diets generally remain near the subsistence level.

\footnotetext{
9United States Department of Agriculture, The World Food Situation and Prospects to 1985, FAE Report No. 98, 1974, pp. 12-14 and 75 .
}

In 1970 per capita calorie and protein consumption in these nations averaged only 69 and 60 percent, respectively, of such consumption in North America. Furthermore, the proportion of food obtained from animal products was only about one-fifth of that in the U.S. ${ }^{10}$

If the LDCs produced a large quantity of non-food products, they could, as Japan has done, achieve higher dietary standards by exchanging such products for food produced by the MDCs. But, total production of all goods per person in the LDCs is relatively low and consists largely of subsistence type products used domestically. In 1972, for example, national income totaled only $\$ 55$ billion in India, $\$ 54$ billion in Brazil, $\$ 16$ billion in Turkey, $\$ 7$ billion in Colombia, and $\$ 2$ billion in Ethiopia. National income totaled $\$ 1,041$ billion in the United States. ${ }^{11}$ A few of the LDCs produce sizable quantities of crops and other commodities for export such as coffee and soybeans in Brazil, sugar in the Philippines, palm oil in Malaysia, feed grains in Argentina, and petroleum in the Organization of Petroleum Exporting Countries (OPEC), but as a general rule their low rate of production does not provide a sufficient quantity of foreign exchange to trade for large quantities of additional food.

Saving and investment in capital goods are appar* ently increasing in the LDCs at a higher rate than population growth, indicating some gains in the per capita stock of capital. The Commission on International Development found that savings and gross investment in these nations totaled 15 and 17.8 percent,

\footnotetext{
10Food and Agricultural Organization of the United Nations, Monthly Btiletin of Agricultural Economics and Statistics (September 1974), pp. 3-6; and USDA, World Agricultural Situation (December 1973), p. 51 .

11United Nations, Monthly Bulletin of Statistics (February 1976).
} 
respectively, of Gross National Product (GNP) during the period 1960-67. However, saving and investment relative to GNP is still very low in the LDCs, averaging well below that of the MDCs.12

Foreign aid has been a source of new capital in many of the LDCs. Such aid has been evident in providing machinery and equipment for industry, for building roads and railways, ports, fertilizer plants, and irtigation facilities. Some of the LDCs, especially the more advanced, have received sizable amounts of private capital. However, few LDCs present a favorable climate for private investment, either from foreign or-local sources. As pointed ont by the Commis sion on Intemational Development, "too few of these countries recognize the tremendous contribution which private investment can make to economic development and in an environment unsympathetic to all private entrepreneurship it is hardly sumprising that foreign investors sense danger." 13 As indicated by D. Gale Johnson a strong case can be made that the major barriers to growth in the LDCs are political in nature. He contends that the barriers to rising per capita food supplies are neither primarily economic nor scientific. However, he suggests that conditions for significant increases in food production include: a major expansion of agricultural research in the developing countries themselves, an adequate supply of modern inputs required to increase yields, the improvement and expansion of the irrigated area, incentives to famers to make the required changes (including the expansion of the cultivated area), and improvements in transportation, marketing, and processing institutions and facilities. In addition, increased investment in human capital and improved communications is desirable, not only because of its contribution to increased agricultural output but also because of the need to assist farm people in the longrun adjustments they must make to economic growth., ${ }^{14}$

The relatively low level of eapital formation in the I.DCs carries over into their investment in knowledge related to food production. In 1965 expenditures on agriculural research and extension services in the LDCs relative to farm production was only about one-half of that in the MDCs. ${ }^{15}$

12 Commission on International Development, Partners in Development (New York: Praeger Publishers, 1969), p. 31.

13 tbid, p. 105 .

14D. Gale Johnson, World Food Problems and Prospects (Washington, D.C.: Anerican Enterprise Institute for Publio Policy Research, June 1975), pp. 77 and 70 .

15obert $Z$. Everson and Yoav Kisler, "Investment in Agricultural Research and Extension: A Survey of Internatioral
The LDCs have achieved some growth in recent years increasing their real GNP at an estimated average rate of 4.8 percent from 1950 to 1967 , or considerably faster than that of the MDCs during their early stage of development. ${ }^{16}$ However, because of the accelerating rate of population growth, per capita income growth has been relatively modest, and many of the LDCs have realized very little, if any, per capita income gains.

Individual nations formerly in the LDC group have managed to move into the $\mathrm{MDC}$ group over time. Occasionally a less developed country begins to make progress. Once a significant amount of progress is made and the political climate for private investment is improved, imported private funds along with enhanced private domestic savings become major sources of development capital. Then the LDCs tend to move into the more developed category of nations. Notable examples of such movements in recent decades have been Japan, Israel, and Greece. Furthermore, once substantial progress has been made few nations have dropped back into the low-productivity class. As long as low production persists, however, the food supplympopulation situation in most of these nations will not have a major impact on food prices in the MDCs.

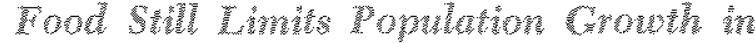 \\ Some Aress...}

Classical theories that population is limited by the mears of subsistence are consistent with the experience in many of the LDCs. People still exist near the subsistence level in many of these nations, and a year or two of below-average crop yields can result in famine, severe malnutrition, and a slower growth or decline in population. India, for example, has experienced a number of major famines since 1800 . Eleven major famines were reported in some parts of the nation since then, as shown in Table II. The longest interval between the major famines listed in these sources was from 1900 to 1943 and other sources list a number of famines even during this interval. ${ }^{17}$

The preponderance of evidence indicates that low per capita production has reduced the rate of popu-

Data," Economic Development and Cultural Change (April $1975)$, p. 510 .

10 Commission on International Development, Partners in Development, p. 27.

${ }^{1}$ See, for example, Rajpat Rai, England's Debt to India (New York: B. W. Huebsch ) 1917 , p. 267 ; and Dr. M. Arokiaswami and T. M. Royappa, The Modern Economic History of India (Madras-2, India: Newman Book House, 1959), p. 335. 


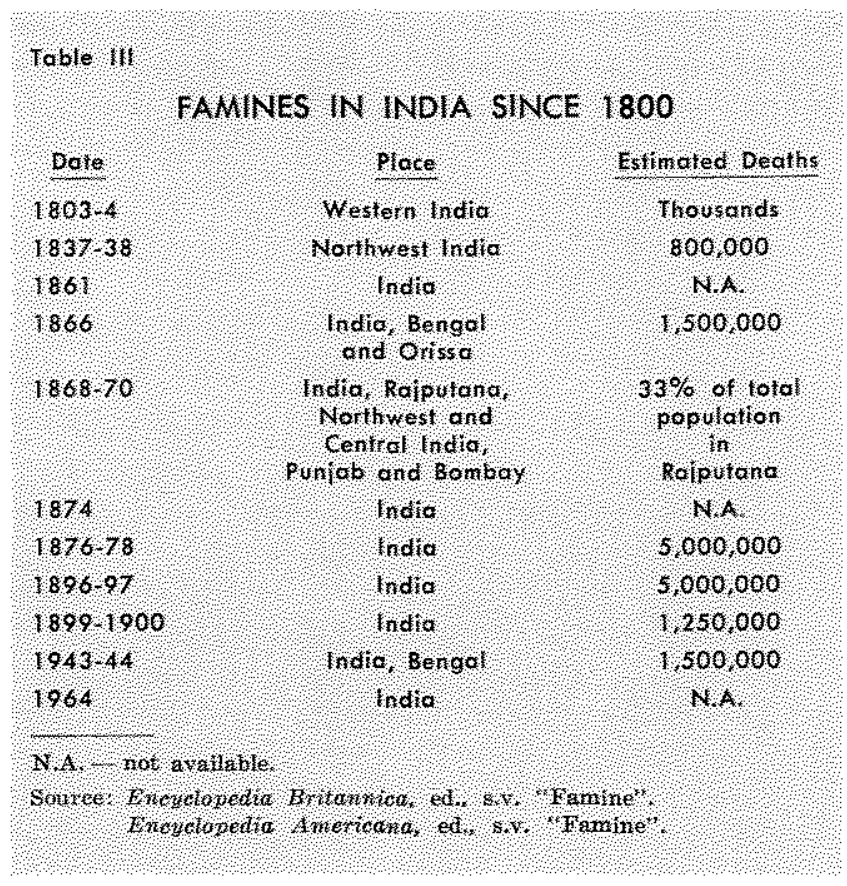

lation growth in India during the past century from what it would have otherwise been. Ansley Coale and Edgar Hoover, using census data, show a small decline in the nation's population from 1891 to 1901 , and growth of less than one-sixth of one percent per year from 1891 to 1921 . They found a fairly constant birth rate, but fluctuating death rates in response to major epidemics and famines. ${ }^{18}$ Rajpat Rat estimated that if the famines had not occurred, the population of India would have been about 40 million greater that it was in $1901 .^{19}$

The acceleration of India's population growth rate in recent decades is also consistent with the classical population-subsistence thesis. For example, during the forty years from 1891 to 1931 , the population remained relatively stable, rising only 0.2 of a percent per year. Available production data for this period indicate little change in per capita wealth and income. Colin Clark calculated that output of all goods and services per breadwinner remained unchanged from 1909-13 to 1935-38. On the basis of NBER estimates GNP per person in the United States during this period grew at an average rate of .9 percent per year. ${ }^{20}$ Coale and Hoover found that since

${ }_{18}$ Ansiley J. Coale and Edgar M. Hoover, population Growth and Economic Development in Low-Income Countries (Princeton: Princeton University Press, 1958), pp. 30-31. ${ }^{19}$ Rajpat Rai, England's Debt, p. 266.

${ }^{20}$ Colin Clark, The Economics of 1960 (London: Macmillan and Company, Ltd., 1944), chart under back cover, and U.S. Department of Conmerce, Long-Term Economic Growth 1860-1965.
1931 both population and food production in India have increased rapidly compared to the earlier period. Population has increased at a 1.8 percent annual rate and food production at a 1.6 percent rate. ${ }^{21}$

The somewhat faster rate of population growth relm ative to food production in India in recent decades can be attributable to a larger volume of food imports, improved internal transportation which facilitated food movements among the various provinces, and improved health practices which limit the deaths caused by diseases associated with malnutrition. Since the late 1940 s imports of food have averaged about 5 percent of total usage, whereas previously the nation was largely self-sufficient. A large percentage of the food imports have been financed by the MDCs under various government aid programs. Fam commodity imports from the U.S., financed largely through Government aid programs, averaged almost $\$ 300 \mathrm{mil}-$ lion per year during the last two decades. ${ }^{22}$ Subsidized food shipments by the United States to India began in 1935-36, but were relatively small until the $1950 \mathrm{~s}$. Then food shipments began to increase sharply under the authority granted in Public Law 480 which provided for the exchange of food for nonconvertible Indian currency.

India has been able to increase yields and production of cereal grains but the gains were not sufficient to offset expanding consumption. From 1960-62 to 1969-71 average yields in India rose at an amual rate of 2 percent and population rose at a rate of 2.6 percent. Production of grains rose at a 3 percent rate, as the acreage planted to grains was increased, but grain consumption rose at a 3.4 percent rate. ${ }^{23}$

While food export subsidy programs of the U.S. and other MDCs have prevented major famines in recent years, the basic causes of malnutrition in India and some other LDCs have not been eliminated. Professor Theodore W. Schultz, who has studied the effects of aid, concluded that such shipments of food products camnot solve the basic malnutrition problem. ${ }^{24}$ In a similar view Harry Walters reported increasing food deficits and a growing dependence on food imports in the traditional agricultural econo-

\footnotetext{
21Coale and Hoover, Population Growth, p. 30; UN Statistical Yearbook; and World Almanac, 1974 ed., S.V. "Tndia".

22USDA Foreign Agricultural Trade of the United States, (May 1974), p. 24.

22U.S.D.A, The World Food Situation and Prospects to 1985, p. 18.

24 Theodore W. Schultz, Economic Crises in World Agriculture

(Arn Arbor: The University of Michigar Press, 1965), p. $3,19$.
} 


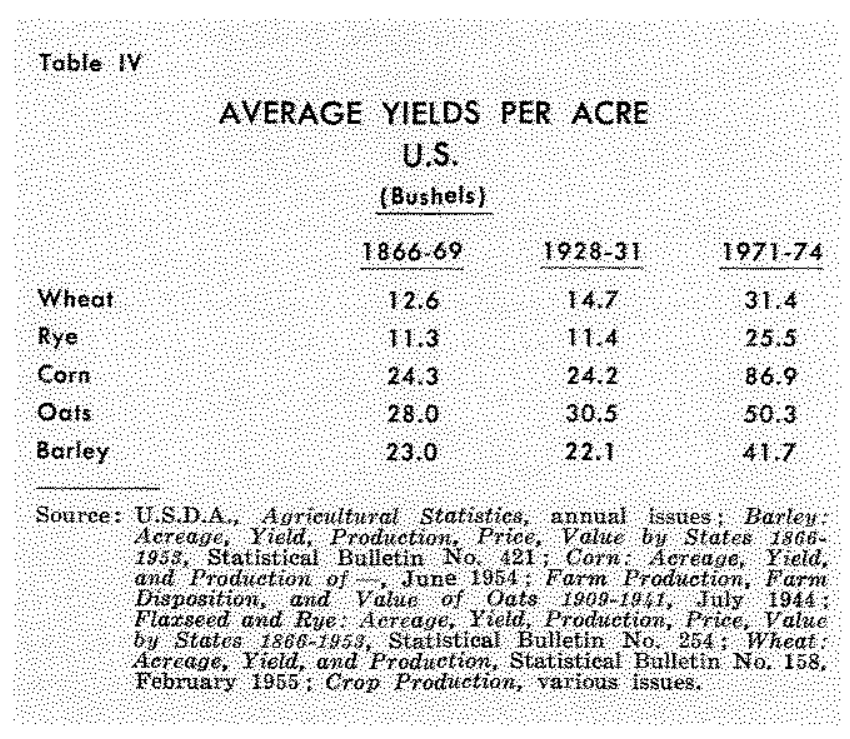

mies such as India. ${ }^{25}$ Thus, the age-old problem of starvation and famine has not disappeared for many people.

Technical assistance programs designed to enhance food output in the LDCs likewise have not significantly altered their food-population relationships. Schultz concluded that in Latin America little real per capita gain has resulted from our contribution of $\$ 44$ million to such programs from 1943 to 1955 . Nine Latin American countries lost ground on a per capita basis, two of which had no programs; and eleven countries gained, one of which received no assistance. On average Latin America's agricultural production increased no faster than the rate of population growth. Hence, very little association existed between such programs and the well-being of the people.20

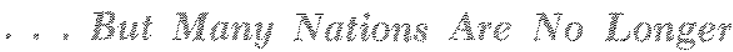

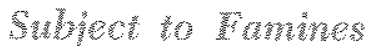

In contrast to the continued threat of famine in many nations, for more than a century no famines have occurred in most of the MDCs. These nations, including the United States, Canada, Western Europe, the U.S.S.R., Australia, and New Zealand, have had relatively low rates of population growth and high rates of capital formation and production. Their populations grew at an average rate of 1.3 percent per year from 1952 to 1962 and at a 1.0 percent rate from 1962 to 1972 (Table II). They produced three-fourths of the world's food output in 1973 and consumed 50

\footnotetext{
25Harry Walters, The World Food Situation (Report to the Committee on Agriculture and Forestry for the 1975 U.S. Agricultural Outlook, December 23, 1974), pp. 20-29.

26Schulta, Economic Crises, p. 55.
}

percent more food per capita than the LDCs. While accounting for only one-fourth of the increase in world population since the mid-1950s they accounted for three-fourths of the increase in world food output. $^{27}$

Those MDCs such as Japan which are not self sufficient in food production produce large quantities of other goods in which they have greater relative efficiency, and exchange such goods with other nations that can produce food more cheaply. Hence, even though they possess few food producing resources, they do not have a serious food-population problem.

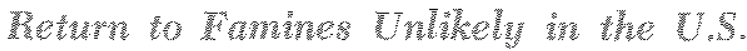

Despite the sharp increase in world food costs in recent years there is little evidence that the MDCs are returning to the economic status of the $\mathrm{LDCs}^{28}$ Real food costs over the long run reflect basic farm product supply and demand conditions, and evidence does not support the view that these conditions have changed toward a reduction in the real food supply in the United States and other MDCs. The long-run food supply factors after adjustment for inflation have moved sharply counter to the classical predictions of universal famines for more than half a century. In contrast to the classical view that crop yields are relatively fixed, and that real retums to land will rise with population growth, the evidence in recent decades supports the opposite view. The importance of the original properties of the soils has declined relative to that of other investments in determining crop yields.

Crop yields in the U.S, were relatively stable from the $1860 \mathrm{~s}$, when yield data were first recorded, until the early 1930s, tending to confirm the classical views. Corn yields averaged 24.3 bushels per acre in the four years 1866-1869, inclusive, and 24.2 bushels per acre in 1928-31 (Table IV). Rye yields were likewise relatively stable during this period. Wheat and oat yields rose somewhat but barley declined. In contrast to the stability of yields prior to the early 1930s, however, yields since then have increased sharply. Com yields have more than tripled, wheat and rye have more than doubled, and oats and barley have almost doubled.

27U.S.D.A., The World Food Situation and Prospects to 1985, pp, $14-16$.

28For an opposite view, see Ehrlich, Population Bomb, po. 44 and 46-47; Brown and Eckholm, "Food and Hunger" pp; 12-24; and Cochrane, "Food Agriculture and Rural Welfare," pp. $989-91$. 
Rising yields since the 1930 s largely reflect the increasing application to land of capital investments in man-made productive factors. The quantity of such yield increasing investments is determined by relative prices and the incentive for invention and discovery. Inventions and discoveries have contributed to more viable seed, heartier and more productive plants, shorter growing season requirements, lower-cost fertilizers, a more balanced supply of plant nutrients, improved weed, disease, and insect controls, crop rotations, soil management, and improved planting, cultivating and harvesting procedures. More efficient machinery and equipment, has led to efficiencies in planting, tillage, harvesting, irrigation, and drainage.

Real wages in the U.S. have also failed to follow the predictions of Mill and other proponents of the classical thesis who contended that population would rise faster than capital formation and reduce wages to the subsistence level. Instead of remaining near the subsistence level real wages in manufacturing have increased in each 20 year period during the last 60 years (Table $\mathrm{V}$ ). Real wages rose at an average rate of two percent per year during the 60-year period. Hence, in contrast to the food-population subsistence theories espoused by the classical economists, major gains in per capita wealth, production, and income, have occurred in the United States. The classical theories of relatively fixed soil productivity, rising rents, and slow rate of capital formation did not envision the extent of man's ability to increase production in the MDCs. Their population theories overestimated man's incentive to multiply and underestimated his wealth accumulations and productive capacity in these nations. As a consequence, the supply of food and other real goods has expanded at a faster rate than population growth.

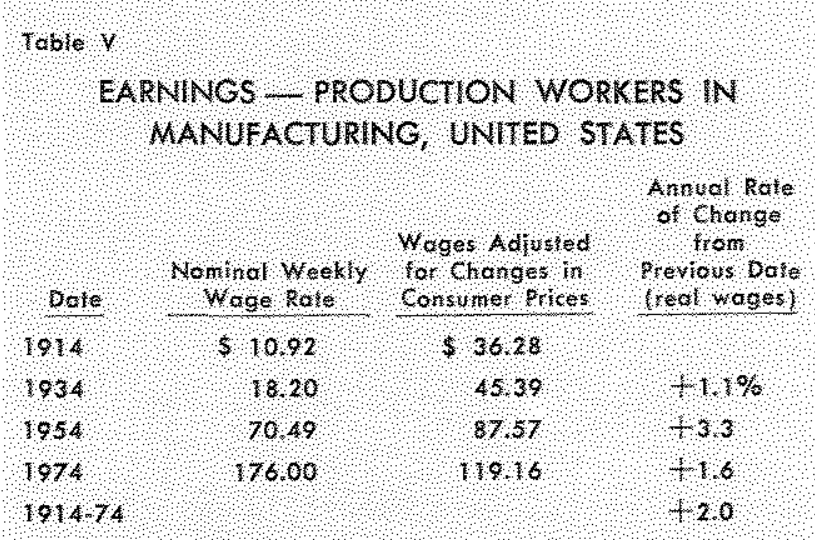

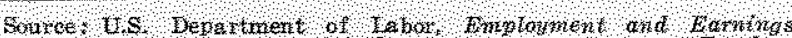

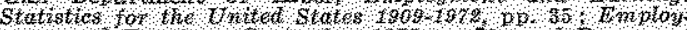

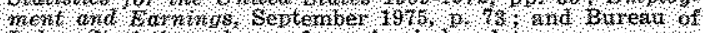

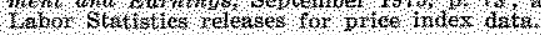

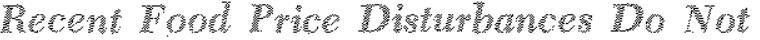

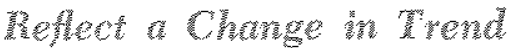

While real food costs in the United States rose sharply in 1973 and 1974, evidence points to shortrun explanations for much of the increase. A number of short-run factors have had a stimulative effect on food prices. Government food subsidies to lower income groups have increased sharply, tending to enhance total food demand since 1969 . The total value of Federal distributions under the Food Stamps, Food Distribution, and Child Nutrition programs of the U.S. Department of Agrictlture rose from $\$ 1.2$ billion in 1969 to $\$ 5.5$ billion in 1974 , and to $\$ 6.8$ billion in 1975 . While these programs may be permanent, the momentum of their upward pressure on food prices should decline if fewer families are hereafter added to the food aid lists.

Demand for food for export was enhanced by relatively unfavorable weather over part of the world. The much publicized Russian wheat sales and the larger grain sales to Westen Europe in 1972 reflected poor crop growing conditions and a sharp increase in production of livestock products in these areas. $A$ sharp cutback in Peruvian fish meal production in late 1972 and 1973, a source of protein for animal feed, also contributed to higher demand for U.S. livestock feed.

A number of factors on the supply side of the domestic market also contributed to the food price increases. Wage-price controls, environmental regulations, relatively poor domestic weather conditions, a sharp increase in fuel costs as a result of the OPEC petroleum monopoly, and changes in the international terms of trade all tended to reduce domestic food supplies from what they would otherwise be.

Domestic wage and price controls in effect during the early 1970s were especially harmful to the food industry. They held the prices of some inputs, such as fertilizer, below long-run equilibrium levels, which reduced the incentive to expand output. Consequently, fertilizer "shortages" developed and, once the controls were lifted, fertilizer prices rose above long-run equilibrium levels. Both the "shortages" and the higher input prices, which followed the lifting of the controls, tended to increase food costs. The freeze on meat prices in the summer of 1973 was also harmful. It reduced the incentive for farmers to prom duce, thus delaying increases in livestock production.

Environmental and safety programs imposed on a wide scale have tended to reduce the supply of all goods and services including food. Controls on chemi- 
cals for crops and on growth additives for livestock feed have both tended to increase farm production costs and reduce food supplies. The OPEC oil cartel which quadrupled the export price of oll has been an important cost-increasing factor since late 1973. Energy costs quickly permeate throughout the economy and affect costs of producing all goods and services.

The depreciation of the dollar relative to other nation's currencies in 1971 was likewise a short-run cost increasing factor. It changed the relative prices of internationally traded goods. Prices of domestic goods to foreign purchasers were reduced and prices of foreign goods to U.S. purchasers were increased. Consequently exports of U.S. agricultural products rose and imports of goods declined resulting in fewer goods for domestic use including food.

None of the above factors appear to be the type that will alter trend movements. Some, such as the environmental protection measures and the oil cartel, will cause only a once-and-for-all reduction in the food supply (reduced quantity supplied at any given price) unless further restrictive measures are taken. On the other hand, per capita wealth is likely to continue upward and the flow of cost-reducing tech nologies into the food industry is likely to be maintained causing the supply of food to continue to increase.

The turnaround in food production and price prospects for food this year relative to other prices is evidence that food prices rose above longer-run equilibrium levels following the short-run disturbances in 1972 and 1973. The disturbances largely affected the prices of grain and other livestock feed. Average feed prices increased sharply leading to reduced output and higher prices for animal food products. But, following the large crop harvested last fall, grain prices declined sharply and all food prices began to level off. Consequently, the spread between food and all consumer prices, that had developed since 1972 , began to close (see chart). During the period of sharply increasing food prices, the percent of U.S. disposable personal income spent on food at home rose, increasing from 12.5 percent in 1972 to 13.1 percent in 1975 . With the turnaround in food prices relative to other consumer goods, the percent of personal income spent on food may resume its downward trend in 1976.

\section{Sumbrat and Condhom}

Fear of famines is not of recent origin. The tendency for population growth to exceed that of food production has been recognized as critical to the well-being

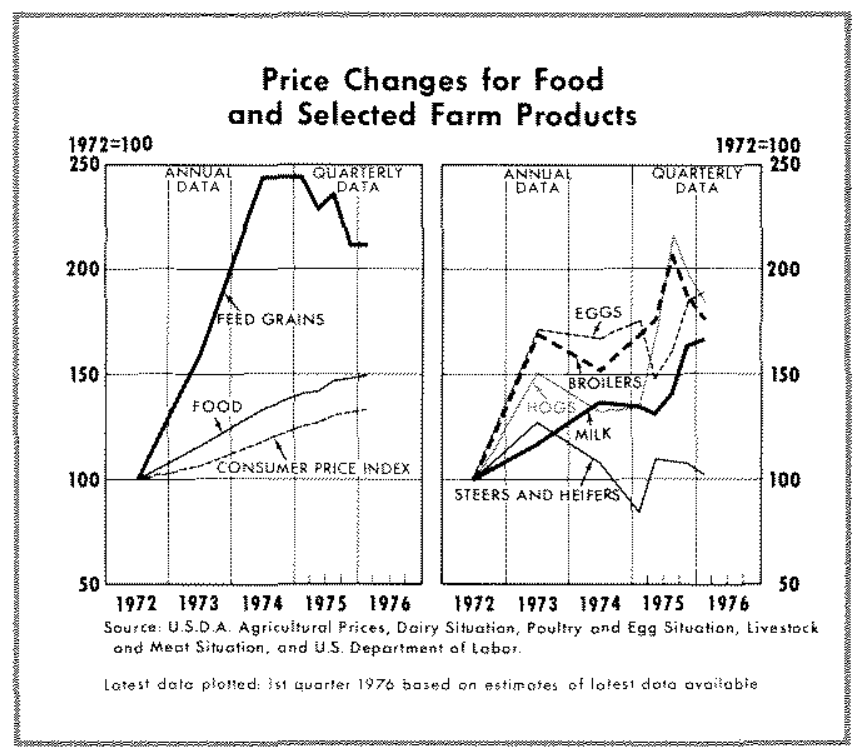

of man throughout history. From time to time some analysts propose that the solution to this imbalance should receive top priority. Others, however, view it as a continuous age-old problem associated $w^{i}$ th wealth accumulation and economic growth. To the latter group the food shortages and starvation in the LDCs is another episode in the classical model of economic development and a problem not stibject to solution by "crash" programs.

The threat of famine is not worldwide. Essentially two worlds exist in terms of per capita food supplies - one, the LDCs, in which growth of population tends to approach that of capital accumulation and productivity, and to be limited by the means of subsistence, and another, the MDCs, in which capital and real per capita income growth is at relatively high rates and population growth is at a relatively low rate.

Famines in the LDCs during the past two decades have been inhibited by food aid programs of the more developed nations. This aid, however, has not improved their per capita productivity. In contrast it may have worsened their food-population relationship.

The success of technical assistance programs for the LDCs has likewise been questioned. Some have suggested that a large portion of future aid be channeled toward a major expansion of research in the LDCs themselves. It is also apparent that progress toward increasing total output could be quickened by providing a more favorable political climate for saving and capital investment in the LDCs. With a more favorable climate for capital investment, technicians which accompany such investment serve to hasten the technical training of the local work force, 
an important factor in achieving rapid gains in production.

While starvation will likely remain a major problem in the LDCs until a sizable increase is achieved in per capita wealth and production, a downtrend in the food supply is not likely to occur elsewhere. Sup" ply and demand conditions in most of the LDCs do not have a major impact on food supplies and prices in the more affluent economies. Although they receive gifts from the MDCs, and some export sizable quantities of goods, most of the LDCs have a relatively small impact on world food prices.

Consequently there is little danger that starvation and famines in the LDCs will spill over into the more developed nations. The MDCs have in recent years experienced some short-run reversals in real food cost but the basic trend in food costs continues downward. The growth of capital, technology, and knowledge in these nations has continued. These factors increase man's ability to produce goods and services. Moreover, there has been no tendency in recent years for their populations to increase at a faster rate than heretofore. Instead of accelerating, their population growth rate has declined. Consequently, instead of a change toward scarcity and famine, once the short-run disturbances are past, the downtrend in real food costs is likely to be resumed.

If the LDGs increase their wealth and develop the capacity to expand output of nonfood goods sufficiently to trade for major quantities of food, such trade would not be detrimental to the well-being of the MDCs. By trading food freely with such nations the MDCs would be able to get more goods and services from their scarce resources than if they produced solely for their own consumption. Consequently, the MDCs have nothing to fear from the possibility of rising productivity and rising food demand in the LDCs.

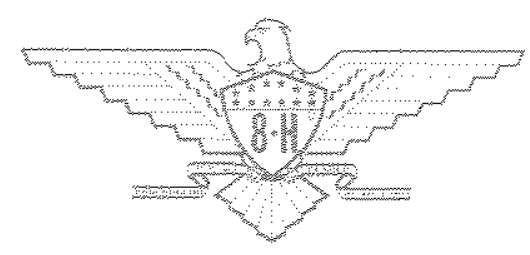

